\title{
Pencegahan COVID-19 dengan pembuatan dan pembagian hand sanitizer di Universitas Muhammadiyah Palopo
}

\author{
Ervianingsih ${ }^{1}$, Chitra Astari ${ }^{*}$, Izal Zahran ${ }^{1}$, Hurria$^{1}$, Murrni Mursyid1, Al Syahril Samsi1 \\ 1Program Studi S1 Farmasi, Fakultas Kesehatan, Pertanian dan Kelautan, Universitas Muhammadiyah Palopo, Palopo, Indonesia
} DOI: https:// doi.org/10.29303/indra.v1i2.31

\section{Article Info}

Received : 24-07-2020

Revised : 23-09-2020

Accepted: 28-09-2020

\begin{abstract}
The purpose of this community service activity was to educate the public to be aware of the spread of COVID-19 while maintaining cleanliness and routine hand washing using soap and running water. Using hand sanitizer is intended when around us having difficulty washing hands using soap and water. The development of the COVID-19 deployment situation caused unrest in the community. One result was panic buying or purchasing necessities and mass cleanliness, such as hand sanitizer products. Answering this, on March 22, 2020, Pharmacy Study Program at The University of Muhammadiyah (UM) Palopo took the initiative to produce hand sanitizers to adjust WHO standards.UM Pharmacy Study Program Palopo successfully produced 50 liters of hand sanitizer which was then distributed to lecturers and staff of the university. The production of hand sanitizers was also to meet the demand of Andi Djemma Palopo Airport, as the airport is one of the entry points for the spread of the COVID-19 virus. Through this community service activity, the products made are useful for overcoming the ongoing pandemic and helping to meet the needs of hand sanitizers.
\end{abstract}

Keywords: Pharmacy, hand sanitizer, community service, prevent COVID-19

Citation: Ervianingsih, E., Astari, C., Zahran, I., Hurria, H., Mursyid, M., \& Samsi, A. S. (2020). Pencegahan COVID-19 dengan pembuatan dan pembagian handsanitizer di Universitas Muhammadiyah Palopo. INDRA: Jurnal Pengabdian kepada Masyarakat, 1(2), 44-48. doi: https:// doi.org/10.29303/indra.v1i2.31

\section{Pendahuluan}

Saat ini Wabah Coronavirus Disease (COVID-19) menjadi isu kesehatan yang paling menghebohkan seluruh dunia, termasuk Indonesia. Penanggulangan ekstrem seperti lockdown suatu daerah bahkan suatu negara pun dilakukan sebagai upaya untuk meminimalisasi penyebaran penyakit tersebut. Belakangan, ternyata ditemukan bahwa diameter virus corona diperkirakan mencapai 125 nanometer atau 0,125 mikrometer. Bahkan World Health Organization (WHO) menyebut virus corona baru (COVID-19) dapat bertahan selama beberapa jam, bahkan beberapa hari dan dapat bertahan hidup di suhu $26-27^{\circ} \mathrm{C}$ (World Health Organization, 2020).

Hal yang disayangkan, penelusuran kasus pertama pada awal Maret 2020 sudah merupakan transmisi lokal dan bukan penularan kasus impor. Masuknya virus tersebut sangat mungkin terjadi melalui pintu-pintu gerbang di beberapa wilayah Indonesia. Berdasarkan data dari World Health Organization (2020), Indonesia juga sudah mulai terpapar oleh virus corona sebanyak 172 orang dengan jumlah kematian sebanyak 55 orang per tanggal 17 Maret 2020.

Langkah-langkah telah dilakukan oleh pemerintah untuk dapat menyelesaikan kasus yang luar biasa ini, salah satunya adalah dengan mensosialisasikan gerakan social distancing. Konsep ini menjelaskan bahwa untuk dapat mengurangi bahkan memutus mata rantai infeksi COVID-19, seseorang harus menjaga jarak aman dengan manusia lainnya minimal 2 meter, dan tidak melakukan kontak 
langsung dengan orang lain, serta menghindari pertemuan massal (CNN Indonesia, 2020). Hal ini yang membuat pemerintah Indonesia telah mengeluarkan status darurat bencana non alam terhitung mulai tanggal 29 Februari 2020 hingga 29 Mei 2020 terkait pandemik virus ini dengan jumlah waktu 91 hari (Koesmawardhani, 2020).

Tindakan pencegahan terhadap jenis penyakit menular tersebut wajib dilakukan secepat mungkin, sesuai dengan Undang-Undang Nomor 6 Tahun 2018, yaitu tentang Kekarantinaan Kesehatan dimana masyarakat perlu membatasi kegiatan sosial (Telaumbanua, 2020).

Peran anggota masyarakat sangat dibutuhkan sebagai upaya untuk melawan COVID-19, memutus mata rantai penyebaran virus Corona dengan melakukan social distancing (menjaga jarak), lockdown, karantina wilayah, tetap menjaga kesehatan dan kebersihan lingkungan, penyediaan Alat Pelindung Diri (APD). Hal yang paling sederhana dan paling efektif menekan dan memutus mata rantai penyebaran COVID-19 adalah untuk tetap di rumah saja, menjaga jarak jika berada di tempat umum atau keramaian, menggunakan masker, mencuci tangan, menggunakan hand sanitizer dan istirahat yang cukup agar kekebalan tubuh tetap terjaga dengan baik (Syafrida, 2020).

Saat ini penggunaan hand sanitizer sudah semakin luas, tidak saja untuk tujuan memelihara kesehatan tangan akan tetapi telah digunakan untuk tujuan-tujuan yang lebih praktis misalnya di rumah makan, di restoran cepat saji, di toilet umum, di rumah sakit, di dalam ruang bedah, di pertanian dan di peternakan (Radji, Suryadi, \& Ariyanti, 2007).

Adapun kelebihan hand sanitizer dapat membunuh kuman dalam waktu relatif cepat, karena mengandung senyawa alkohol (etanol, propanol, isopropanol) dengan konsentrasi $\pm 60 \%$ sampai $80 \%$ dan golongan fenol (klorheksidin, triklosan). Senyawa yang terkandung dalam hand sanitizer memiliki mekanisme kerja dengan cara mendenaturasi dan mengkoagulasi protein sel kuman (Asngad \& Bagas, 2018).

Hand sanitizer merupakan suatu produk sediaan cair yang penggunaannya tanpa menggunakan air. Produk ini berfungsi sebagai pemberi aroma yang sehat dan segar pada tangan sekaligus dapat membunuh kuman, yang saat ini banyak digemari oleh masyarakat untuk pemeliharaan kebersihan dan kesehatan tangan, serta mencegah pencemaran kuman pada saat hendak konsumsi makanan (Fatimah \& Ardiani, 2018).

Penggunaan hand sanitizer merupakan salah satu metode memutus penyebaran virus dari pasien atau carrier kepada orang lain. Produk ini memiliki kemampuan untuk membunuh virus, tetapi karena kebutuhan pasar yang melonjak tinggi menyebabkan hand sanitizer sulit ditemukan di pasaran. Kebutuhan hand sanitizer saat ini tidak bisa mengandalkan produk dari industri yang selama ini beredar, diperlukan produksi tambahan oleh institusi yang memiliki kompetensi untuk mendapatkan produk yang baik. Kondisi inilah yang mendorong Program Studi (Prodi) Farmasi Universitas Muhammadiyah Palopo untuk membuat produk hand sanitizer sesuai standar WHO.

Program Studi Farmasi Universitas

Muhammadiyah Palopo yang memiliki kompetensi keilmuan dan sumber daya manusia dalam bidang teknologi formulasi sediaan farmasi memproduksi hand sanitizer untuk didistribusikan kepada pihak-pihak yang membutuhkan. Kegiatan ini dikemas dalam kerangka pengabdian kepada masyarakat program pembuatan dan distribusi hand sanitizer yang dilaksanakan pada tanggal 22 Maret 2020 oleh dosen dan mahasiswa.

Cara penggunaan hand sanitizer juga dipaparkan agar dilakukan hanya sewaktu waktu ketika berada di luar rumah. Pada saat di dalam rumah dianjurkan tetap mencuci tangan menggunakan sabun, mengingat bahan bahan hand sanitizer merupakan bahan yang membuat kulit menjadi kering jika dipakai secara terus menerus (Meri, Khusnul, Rochmanah, Suhartati, Mardiana, \& Nurpalah, 2020).

\section{Metode}

Metode yang digunakan adalah praktek kerja langsung di tempat dan dilaksanakan pada tanggal 22 Maret 2020 di Laboratorium Prodi Farmasi Universitas Muhammadiyah Palopo. Kegiatan diawali dengan perkenalan ketua dan anggota tim pengabdian Prodi Farmasi, Universitas Muhammadiyah Palopo, kemudian dilanjutkan dengan penyampaian materi tentang informasi COVID-19, upaya pencegahan penyebaran COVID-19, dan cara pembuatan hand sanitizer. Setelah semua materi disampaikan, dilanjutkan ke sesi pembuatan hand sanitizer. Alat yang digunakan pada pelatihan ini adalah pipet tetes kaca, gelas ukur $100 \mathrm{ml}$, gelas beaker $1000 \mathrm{ml}$, botol sprayer, corong kaca, kertas saring. Pembuatan hand sanitizer dibuat berdasarkan standar $\mathrm{WHO}$, yaitu dengan menggunakan bahan alkohol 96\%, gliserol 98\%, $\mathrm{H}_{2} \mathrm{O}_{2}$ $3 \%$ dan akuades. Bahan-bahan ini memiliki fungsi sebagai antimikroba, disertai bahan yang dapat menjaga kelembaban kulit yaitu berasal dari gliserol (World Health Organization, 2010).

\section{Hasil dan Pembahasan}

Mengantisipasi penyebaran virus corona, tim pengabdian masyarakat Prodi Farmasi Universitas Muhammadiyah Palopo membuat dan menyalurkan 50 liter hand sanitizer (cairan pembersih tangan) kepada 
staf dan dosen di lingkungan Universitas Muhammadiyah Palopo.

Kegiatan dilaksanakan pada 22 Maret 2020. Kegiatan ini merupakan program pengabdian masyarakat diketuai oleh apt. Ervianingsih, S.Farm., M.Si. Program ini terlaksana sebagai bentuk sumbangsih kepada masyarakat akibat langka dan melonjaknya harga cairan antiseptik berupa hand sanitizer di pasaran semenjak pandemi COVID-19 ini seperti yang terlihat pada Gambar 1 dan Gambar 2.

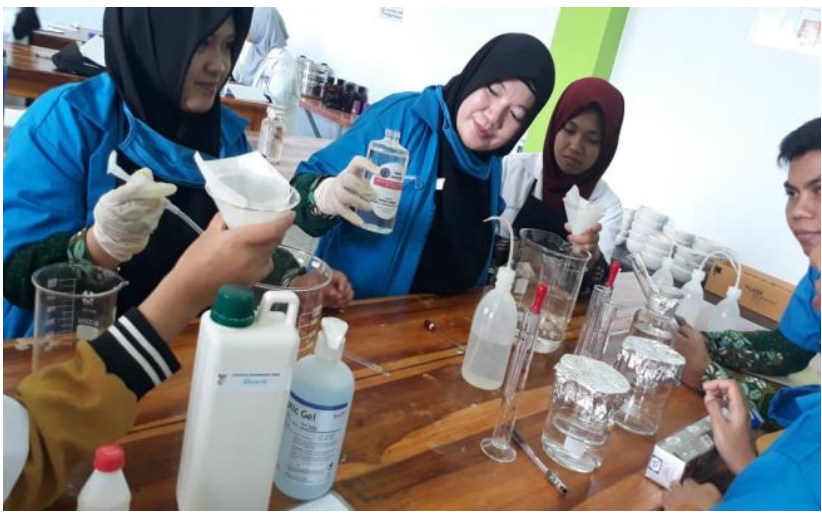

Gambar 1. Proses pembuatan hand sanitizer sesuai standar $\mathrm{WHO}$

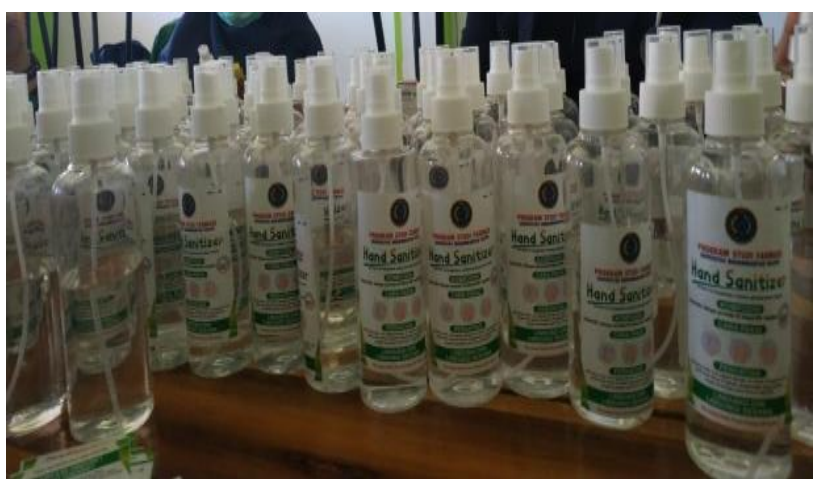

Gambar 2. Produk hand sanitizer yang siap dibagikan

Kegiatan ini merupakan aksi nyata pengabdian masyarakat oleh dosen Farmasi Universitas Muhammadiyah Palopo. Seperti yang kita ketahui bersama, menjaga kebersihan diri dan membersihkan tangan secara teratur menggunakan cairan antiseptik yang mengandung alkohol adalah salah satu upaya mencegah penularan COVID-19.

Kegiatan pengabdian kepada masyarakat ini akan menyalurkan 50 liter dimana pada tahap ini, tim pengabdian masyarakat (Gambar 3) telah membagikan kepada staf dan dosen di lingkungan Universitas Muhammadiyah Palopo dan juga di Bandar Udara Andi Djemma Masamba. Hand Sanitizer tersebut merupakan hasil karya Jurusan Farmasi dengan mengikuti formula hand sanitizer dari WHO.

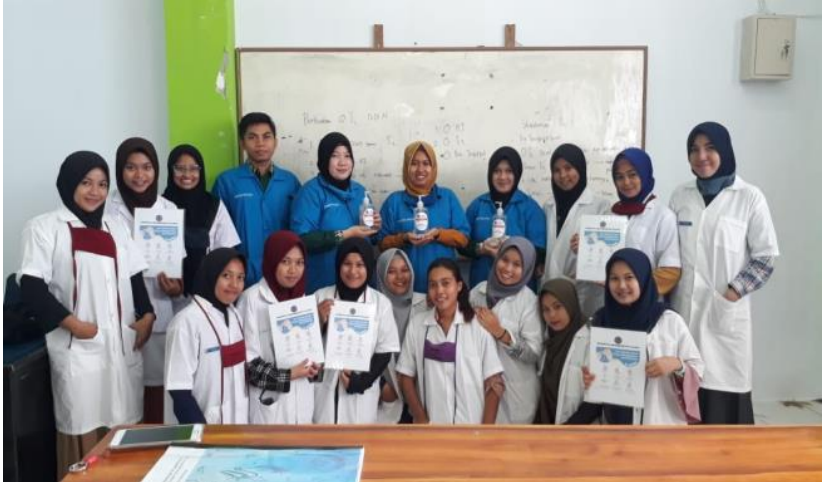

Gambar 3. Tim pengabdian masyarakat Prodi Farmasi Universitas Muhammadiyah Palopo bersama mahasiswa

Kegiatan ini merupakan kegiatan pembuatan dan pembagian hand sanitizer pertama di masa awal pandemik COVID-19 di Kota Palopo, Sulawesi Selatan, dan juga Prodi dan Universitas pertama di Kota Palopo yang melakukan kegiatan tersebut sehingga banyak media massa yang meliput untuk memberitakan kegiatan tersebut (Gambar 4) dan kami berharap semoga kegiatan ini menjadi contoh bagi instansi lain yang berkompeten untuk bisa melakukan hal yang sama.

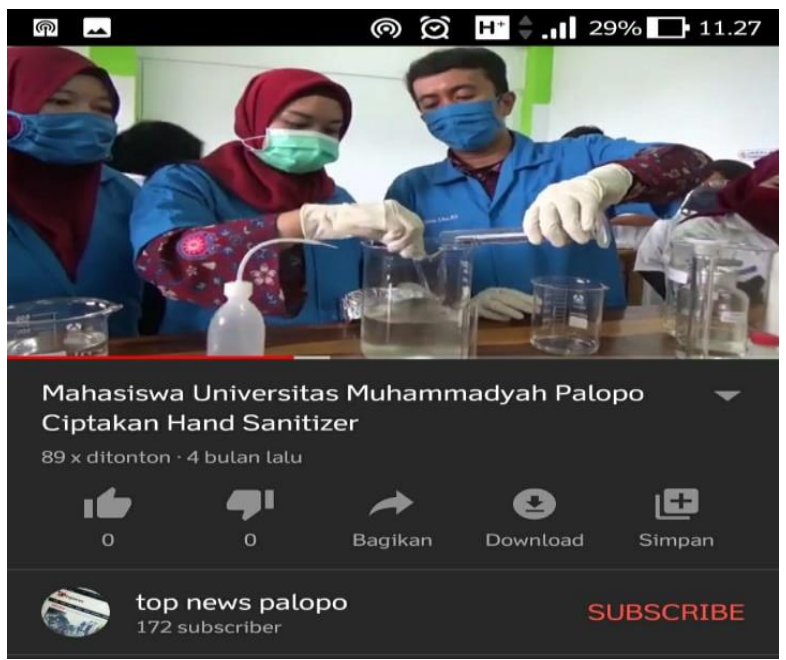

Gambar 4. Kegiatan pengabdian masyarakat diliput oleh beberapa media

Untuk mengetahui efektivitas dan kebermanfaatan penyelenggaraan pengabdian dilakukan dengan cara mewawancarai pihak staf dan dosen serta mahasiswa di lingkungan Universitas Muhammadiyah Palopo, di antaranya Rektor Universitas Muhammadiyah Palopo, Dr. Salju, SE.,MM. (Gambar 5), yang mengatakan, "Ini adalah upaya Fakultas Kesehatan, Prodi Farmasi khususnya dalam mencegah penyebaran virus COVID-19 di lingkungan universitas dan di masyarakat semoga bermanfaat untuk kita semua". 


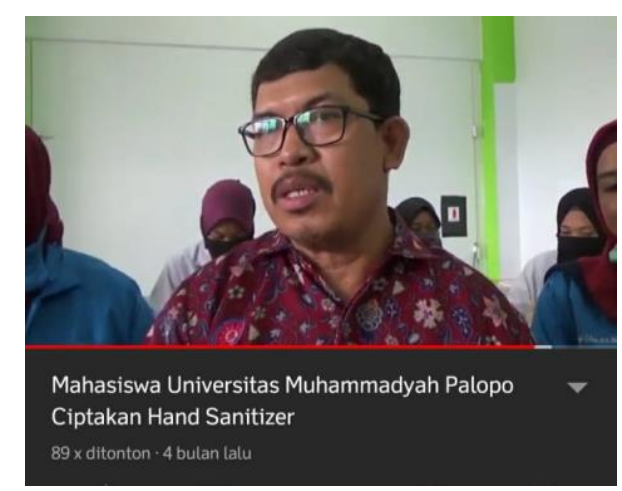

Gambar 5. Wawancara Rektor Universitas Muhammadiyah Palopo oleh media

Memutus mata rantai penyebaran virus ini dapat dilakukan mulai dari hal yang kecil seperti rajin mencuci tangan menggunakan air mengalir dan sabun atau menggunakan hand sanitizer. Hal ini sangat berdampak besar untuk menghentikan penyebaran virus ini.

Selain itu, menghadapi masa seperti ini sebaiknya kita tetap berfikir positif dan berperilaku positif. Panic buying merugikan banyak orang apalagi masyarakat dengan ekonomi lemah karena selain menyebabkan kekosongan stok, panic buying juga menyebabkan harga menjadi melonjak tajam. Kita sebagai sesama manusia harusnya bisa berpikir bijak dalam menghadapi pandemik COVID-19 ini.

Tim pengabdian masyarakat berharap agar hand sanitizer ini dapat menjadi cairan pembersih tangan bagi mereka yang tidak memiliki akses cuci tangan dengan air dan sabun setiap saat. Semoga hand sanitizer ini dapat bemanfaat untuk mendukung masyarakat hidup bersih dan sehat dalam rangka melawan COVID-19.

\section{Simpulan}

Telah dilaksanakan kegiatan pengabdian masyarakat di Universitas Muhammadiyah Palopo, Kota Palopo. Kegiatan pengabdian masyarakat ini diikuti oleh seluruh staf dan dosen serta mahasiswa. Kegiatan berjalan dengan lancar dan mendapat dukungan penuh dari civitas akademika. Dari kegiatan tersebut, diharapkan produk hand sanitizer ini dapat bermanfaat untuk staf dan dosen serta mahasiswa di Universitas Muhammadiyah Palopo, masjid sekitar dan Bandar Udara Andi Djemma Masamba. Semoga kedepannya Prodi Farmasi Universitas Muhammadiyah Palopo dapat lebih banyak menghasilkan produk yang bermanfaat untuk masyarakat sekitar dan dapat melaksanakan pengabdian masyarakat dengan mengangkat isu-isu terbaru yang beredar di masyarakat.

\section{Ucapan Terima Kasih}

Kami tim pengabdian masyarakat Program Studi Farmasi Universitas Muhammadiyah Palopo, mengucapkan terima kasih kepada seluruh dosen dan staf Universitas Muhammadiyah Palopo untuk kerjasama dan kontribusinya terhadap kelancaran kegiatan pengabdian masyarakat ini.

\section{Daftar Pustaka}

Asngad, A., \& Bagas, A. R. (2018). Kualitas gel pembersih tangan (handsanitizer) dari ekstrak batang pisang dengan penambahan alkohol, triklosan dan gliserin yang berbeda dosisnya. Jurnal Bioeksperimen, 4(2), 6170.https://doi.org/10.23917/bioeksperimen.v4i1.27 95

CNN Indonesia. (2020). Mengenal social distancing sebagai cara mencegah corona. Retrieved March 14, 2020, from https://www.cnnindonesia.com/gayahidup/20200314102823-255-483358/mengenalsocial-distancing-sebagai-cara-mencegah-corona.

Fatimah, C., \& Ardiani, R. (2018). Pembuatan hand sanitizer (pembersih tangan tanpa air) menggunakan antiseptik bahan alami. Prosiding Seminar Nasional Hasil Pengabdian, 1(1), 336-343.

Koesmawardhani, N. W. (2020). Pemerintah tetapkan masa darurat bencana corona hingga 29 Mei 2020. Retrieved April 13, 2020, from https://news.detik.com/berita/d4942327/ pemerintah-tetapkan-masa-daruratbencana-corona-hingga-29-mei-2020.

Meri, M., Khusnul, K., Suhartati, R., Mardiana, U., \& Nurpalah, R. (2020). Pemberdayaan masyarakat dalam penggunaan hand sanitiser dan masker sebagai upaya preventif terhadap COVID-19. Bantenese Jurnal Pengabdian Masyarakat, 2(1), 26-33.

Radji, M., Suryadi, H., \& Ariyanti, D. (2007). Uji aktivitas antimikroba beberapa merek dagang pembersih tangan antiseptik. Majalah Ilmu Kefarmasian, 4(1), 1-6. https://doi.org/10.1109/ICNSURV.2011.5935263

Syafrida, S. (2020). Bersama melawan virus COVID-19 di Indonesia. SALAM: Jurnal Sosial dan Budaya Syar-I, 7(6). https://doi.org/10.15408/sjsbs.v7i6.15325

Telaumbanua, D. (2020). Urgensi pembentukan aturan terkait pencegahanCOVID-19 di Indonesia. QALAMUNA: Jurnal Pendidikan, Sosial, dan Agama, 12(01), $59-$ 70.https://doi.org/10.37680/qalamuna.v12i01.290 
World Health Organization. (2010). Guide to local production: WHO-recommended handrub formulations (No.WHO/IER/PSP/2010.5). World Health Organization.

World Health Organization. (2020). Coronavirus disease 2019 (COVID-19). Retrieved September20, 2020, fromhttps://www.who.int/emergencies/diseases/ novel-coronavirus-2019 